\title{
LOW MALARIA MORBIDITY IN A COHORT OF SENEGALESE CHILDREN WITH FREE ACCESS TO HEALTH STRUCTURES
}

\author{
VALIN N.*, DIENG A.B.*, CHIPPAUX J.P.**, LE HESRAN J.Y.*, GAYE O.*** \& GARCIA A.*
}

\section{Summary:}

We report the impact of the free access to health facilities on malaria morbidity in children from two to 15 years old, during a malaria transmission season in Niakhar, Senegal. Between July and December 2002, 227 malaria attacks occured in 566 children. Only one case of severe malaria was observed and no death has been reported. Our results demonstrate furthermore that easier access to health facilities and to early treatment is playing a key role in malaria control.

KEY WORDS : malaria, children, health structures, treatment policy, drug resistance, Senegal.

$\mathrm{M}$ alaria remains one of the main causes of mortality and morbidity in children in Sub-Saharian Africa. In the last fifteen years, the development of P. falciparum's resistance to the widely used antimalarial drugs contributed to worsen these figures. A significant number of malaria attacks or deaths might be avoided by a correct diagnosis, an early treatment and an easier access to health structures and drugs. This paper reports the follow-up of a children's cohort during malaria transmission season between July and October 2002 in Senegal. During this survey, free access to local health structures and drugs was organised. Our objectives were to describe malaria morbidity among this cohort and the treatment schedules used by nurses in this particular context.

\section{MATERIAL AND METHODS}

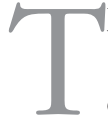
his study was carried out in the Niakhar area, $115 \mathrm{~km}$ south-east from Dakar, Senegal, as part of a research program on genetic factors invol-

\footnotetext{
* Institut de Recherche pour le Développement (IRD), Unité de Recherche (UR) 010 : Santé de la mère et de l'enfant en milieu tropical, Dakar, Sénégal.

** IRD, Unité de Service (US) 009, Dakar, Sénégal.

**** Laboratoire de Parasitologie et de Mycologie, Faculté de Médecine, Université Cheikh Anta Diop (UCAD), Dakar, Sénégal. Correspondence: Dr André Garcia, UR 10, 01 BP 4414, R.P., Cotonou, Bénin.

Tel.: (229) 21300354 - Fax: (229) 21308860.

Email: Andre.Garcia@ird.fr
}

Résumé : FAIBLE MORBIDITÉ PALUSTRE ET ACCÈS GRATUIT AUX STRUCTURES DE SOINS DANS UNE COHORTE D'ENFANTS SÉNÉGALAIS Cette étude décrit les effets du libre accès aux structures de soins parmi 566 enfants âgés de deux à 15 ans, pendant une saison de transmission palustre au Sénégal. Entre juillet et décembre 2002, 227 cas d'accès palustres ont été diagnostiqués. Un seul cas d'accès palustre sévère a été décrit et aucun décès n'a été signalé. Nos résultats soulignent que l'accès facilité aux structures de soins et un traitement précoce sont des éléments majeurs dans la lutte contre le paludisme.

MOTS CLÉS : paludisme, enfant, structure de soins, recommandation, traitement, Sénégal.

ved in resistance or susceptibility to malaria (Garcia et al., 2004). Niakhar has been an observatory for population and health studies since 1962. Data about birth, residence or deaths is collected by investigators for all the inhabitants (Chippaux et al., 2001). Malaria transmission occurs almost exclusively between September and October in this area (Robert et al., 1998). The verbal autopsy method was developed to determine the reasons of death by post mortem interview of relatives (Etard et al., 2004).

This follow-up was carried out in a cohort of 566 children, from Diohine and Toucar, two villages in the Niakhar area. This research program has been accepted by the ethic committee of the Health Minister of Senegal ( $\mathrm{N}^{\circ}$ 000526/MS/DERF/DER).

From July 2002, parents were instructed to conduct to the dispensary any sick child. Furthermore, each of these 566 children was visited twice a week at home by trained Primary Health Agents (PHA) who checked body temperature. In case of axillary temperature greater or equal to $37.5^{\circ} \mathrm{C}$ or in case of history of fever, the parents were invited to go to the dispensary. During this study, the nurses treated patients according to the national guideline. For presumptive malaria, chloroquine was administered as first-line treatment, sulfadoxine-pyrimethamine (SP) as second-line and quinine as third-line treatment.

For each child with fever or history of fever, a thick blood smear was examined and a questionnaire related to clinical signs (axillary temperature, headache, vomi- 
ting, anaemia, convulsion or coma) and previous treatment taken was filled out. Microscopy can not be operated in the health centres, and presumptive malaria treatment was given as recommended by WHO (Gomes et al., 1994). During cross sectional surveys, chloroquinuria assays were performed between September and November 2002, using the Haskins and Mount method (Cot et al., 1991).

A febrile attack (FA) was defined by an axillary temperature greater or equal to $37.5^{\circ} \mathrm{C}$ or reported history of fever. A malaria attack (MA) was defined by the presence of a FA with a $P$. falciparum parasite density above 2,500 trophozoites/ $\mu$ l (Rogier et al., 1996). Two MA within two weeks were not considered as independent.

The data was processed using Epi-Info and analysed with STATA version 6. Pearson chi-square test or Fisher exact test were used for categorical variables and Student $\mathrm{t}$ test for quantitative variables. For all analyses, the significance level retained was 0.05 .

\section{RESULTS}

$\mathrm{F}$ rom July to December 2002, 566 children from 1 Diohine (304) and Toucar (262) were followed up. The sex-ratio was 1.2 and the mean age was 9.0 years (two to 15 years old, $s d \pm 3.4$ ). Among the 566 children, we registered 669 consultations for fever. Children who suffered of at least one FA were significantly younger $(\mathrm{p}<0.01)$ than children who never consulted (8.5 years and 9.9 years respectively).

Among the 669 FA, 355 (53.1\%) had a positive parasite density and 227 (33.9\%) were classified as malaria attack. Among the 566 children, 141 (24.9\%) experienced one MA, and $40(7.1 \%)$ more than one MA. The incidence of MA decreased significantly with age $(\mathrm{p}<$ 0.001) from $0.7 \mathrm{MA}$ per child during the study period for children younger than five, to 0.4 for children between six and ten, and 0.25 for children older than ten years. Neurological signs were extremely rare (one case of convulsion, no coma). Vomiting and clinical anaemia were significantly more frequent during MA than FA $(p=0.04)$ (Table I). Between July and December 2002, no death was reported among children from the cohort. During the same period, in the same villages and for the same age group but among children not included in this follow-up $(n=2,148)$ eight children died including four from malaria and one from meningitis. For the remaining three cases, the cause of death has not been determined.

In case of MA, chloroquine was used in 171 cases (75.3\%), but was associated to quinine in 97 (56.7\%) cases. Quinine was prescribed alone in 31 cases, and in association with sulfadoxine-pyrimethamine (SP) in four cases. SP and amodiaquine were prescribed alone

\begin{tabular}{lccc}
\hline & $\begin{array}{c}\text { Malaria } \\
\text { attacks } \\
(\mathrm{N}=227)(\%)\end{array}$ & $\begin{array}{c}\text { Other } \\
\text { febrile attacks } \\
(\mathrm{N}=436)(\%)\end{array}$ & \multicolumn{1}{c}{$\mathbf{P}^{*}$} \\
\hline Headache & $226(99.6)$ & $431(98.9)$ & $\mathrm{ns}$ \\
Vomiting & $110(48.5)$ & $74(17.0)$ & $<0.001$ \\
Clinical anaemia & $58(25.6)$ & $77(17.7)$ & 0.02 \\
Neurological signs & $1(0.4)$ & $5(1.1)$ & $\mathrm{ns}$ \\
\hline
\end{tabular}

* Fisher exact test.

Table I. - Clinical signs associated with malaria attacks or febrile access.

\begin{tabular}{lccc}
\hline & $\begin{array}{c}\text { First MA } \\
(\mathbf{N}=\mathbf{1 8 1}) \\
\mathbf{N}(\%)\end{array}$ & $\begin{array}{c}\text { Second MA } \\
(\mathbf{N}=\mathbf{4 0}) \\
\mathbf{N}(\%)\end{array}$ & $\begin{array}{c}\text { Third MA } \\
\mathbf{( N = 6 )} \\
\mathbf{N}(\%)\end{array}$ \\
\hline Chloroquine & $133(73.5)$ & $32(80.0)$ & $6(100.0)$ \\
$\quad$ alone & $55(41.4)$ & $16(50.0)$ & $4(66.7)$ \\
$\quad$ with quinine & $78(58.6)$ & $16(50.0)$ & $2(33.3)$ \\
Quinine & $111(61.3)$ & $2(5.0)$ & \\
$\quad$ alone & $29(26.1)$ & & \\
$\quad$ with chloroquine & $78(70.3)$ & & \\
$\quad$ with SP* & $4(3.6)$ & $3(7.5)$ & \\
SP* & $7(3.9)$ & $2(5.0)$ & \\
Amodiaquine & $7(3.9)$ & & \\
No treatment & $1(0.6)$ & $1(2.5)$ & \\
Unknown treatment & & & \\
\hline
\end{tabular}

* Sulfadoxine-pyrimethamine

Table II. - Treatment of malaria attacks (MA).

in ten and nine cases respectively. 29 (22.0\%) of the quinine-treated children presented neither vomiting, anaemia, neurological signs (i.e. classical indications), suggesting that quinine was not appropriate in these cases. One child did not receive anti malarial treatment and the treatment was unknown for one case (Table II). One child attended to dispensary twice in eleven days suggesting a treatment failure.

Chloroquinuria assays were performed to estimate the real use of chloroquine and its anarchic use. Taking into account both the date of MA diagnostic's, the date of urine sampling and considering that chloroquine metabolites in urine could be detected during three weeks, urine samplings were analysed for 104 among the 227 MA. Among these 104 children, 26 did not receive any prescription of chloroquine. However, eight (31\%) of them had chloroquine metabolites in urines suggesting self-treatment. Conversely, 29 (37\%) of the 78 children who were supposed to have received chloroquine had no urinal chloroquine metabolites.

\section{DISCUSSION}

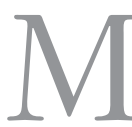
orbidity results concerning during the followup of this cohort are quite similar to previous studies in different areas of Senegal (Trape et al., 1987, 1993). The most interesting results concern the 
treatment strategy used in this context considering the availability of all drugs at the health facility, and the free access to health centers for the population. Our results show that in spite of the high level of chloroquine resistance reported in this area (Sokhna et al., 1997), we did not note any return to dispensary in the children who had received this treatment. The only treatment failure occured in one child who received one or two quinine perfusions, as it is the practice. Only one severe malaria attack occurred, and no death has been reported.

Our study suggests that early diagnosis and treatment of uncomplicated malaria can reduce severe malaria-associated morbidity and mortality, as already showed by a study carried out in Vietnam (Giao et al., 2005). In the same perspective, several others studies in Africa pointed out the fact that easy health access is an interesting tool to reduce malaria morbidity (Hill et al., 2000 in The Gambia; Sirima et al., 2003 in Burkina Faso). However, our study differs strongly from these two previous studies by the fact that treatments were not controlled. This study also shows that quinine was often prescribed without proper indication. The results of urine assays suggest the reality of self-treatment and the frequent lack of compliance to the treatment, as reported in others studies (Abuya et al., 2005; Olaogun et al., 2005). These results have been communicated to the health authorities to help them improve the training of the medical staff in dispensaries and to try to reduce these treatment misuses. Among strategies to reduce malaria burden, treatment guidelines changes were proposed, justified by the increasing of chloroquine resistance. SP and amodiaquine combination has been the official recommendation in Senegal since August 2003. Taking account the therapeutic anarchy recorded within our cohort, this policy change would probably be difficult to get applied, and should be strongly associated with the training of health workers and the population. However, we should not neglect the role of the easier and the earlier access to health facilities as an important tool for disease control.

\section{ACKNOWLEDGEMENTS}

T This work was supported by the French Research Ministry Programme PAL+ (2001 and 2002) and by the Institut de Recherche pour le Développement (IRD). We thank all the inhabitants and the Health Care Agents of Diohine and Toucar, and the US009 from IRD. We are also grateful to the UR010 team.

\section{REFERENCES}

Abuya T.O., Molynuex C.S., Orago A.S., Were S. \& Marsh V. Quality of care provided to febrile children presenting in rural private clinics on the Kenyan coast. African Health Science, 2004, 4, 160-170.
Chippaux J.P. The Niakhar study zone in Senegal. Med. Trop., 2001, 61, 131-135.

Cot M., Gineste B., Barro D., Roisin A., Yada A. \& CarneVALE P. Comparison of two field methods for urinary assay of chloroquine. Annales de la Société Belge de Médecine Tropicale, 1991, 71, 17-25.

Etard J.F., Le Hesran J.Y., Diallo A., Diallo J.P., Ndiaye J.L. \& Delaunay V. Childhood mortality and probable causes of death using verbal autopsy in Niakhar, Senegal, 19892000. International Journal of Epidemiology, 2004, 33, 1286-1292.

Garcia A., Dieng A.B., Rouget F., Migot-Nabias F., Le Hesran J.Y. \& GAYE O. Role of environment and behaviour in familial resemblances of Plasmodium falciparum infection in a population of Senegalese children. Microbes Infect, 2004, 6, 68-75.

Giao P.T., de Vries P.J., Binh T.Q., Nam N.V. \& Kager P.A. Early diagnosis and treatment of uncomplicated malaria and patterns of health seeking in Vietnam. Tropical Medicine Int. Health, 2005, 10, 919-925.

Gomes M., Espino F.E., Abaquin J., Realon C. \& Salazar N.P. Symptomatic identification of malaria in the home and in the primary health care clinic. Bull. World Health Organisation, 1994, 72, 383-390.

Hill A.G., Mac Leod W.B., Joof D., Gomez P. \& Walraven G. Decline of mortality in children in rural Gambia: the influence of village-level Primary Health Care. Tropical Medicine Int. Health, 2000, 5, 107-118.

Olaogun A.A., Ayandiran O., Olasode O.A., Adebayo A. \& OMOKHODion F. Home management of childhood febrile illnesses in a rural community in Nigeria. Australian Journal of Rural Health, 2005, 13, 97-101.

Robert V., Dieng H., Lochouran L. et al. Malaria transmission in the rural zone of Niakhar, Senegal. Tropical Medicine Int. Health, 1998, 3, 667-677.

Rogier C., Commenges D. \& Trape J.F. Evidence for an agedependent pyrogenic threshold of Plasmodium falciparum parasitemia in highly endemic populations. American Journal of Tropical Medicine and Hygiene, 1996, 54, 613-19.

Sirima S.B., Konate A., Tiono A.B., Convelbo N., Cousens S. \& PAGNONI F. Early treatment of childhood fevers with prepackaged antimalarial drugs in the home reduces severe malaria morbidity in Burkina Faso. Tropical Medicine Int. Health, 2003, 8, 133-139.

Sokhna C.S., Molez J.F., Ndiaye P., Sane B. \& Trape J.F. In vivo chemosensitivity tests of Plasmodium falciparum to chloroquine in Senegal: the development of resistance and the assessment of therapeutic efficacy. Bulletin de la Société de Pathologie Exotique, 1997, 90, 83-89.

Trape J.F., Zoulani A. \& QuineT M.C. Assessment of the incidence and prevalence of clinical malaria in semi-immune children exposed to intense and perennial transmission. American Journal of Epidemiology, 1987, 126, 193-201.

Trape J.F., Lefebvre Zante E., Legros F. et al. Malaria morbidity among children exposed to low seasonal transmission in Dakar, Senegal and its implication for malaria control in tropical Africa. American Journal of Tropical Medicine and Hygiene, 1993, 48, 748-756.

Reçu le 31 mai 2005 Accepté le 9 novembre 2005 